\title{
Influence of extracurricular fertilization on growth, development, quality indicators and grain yield of winter wheat
}

\author{
Bakhrom Azizov $^{1 *}$, Shavkat Djabborov ${ }^{1}$, Saodat Asatova ${ }^{1}$, and Nodira Kuchkorova ${ }^{1}$ \\ ${ }^{1}$ Tashkent State Agrarian University, 100140, Tashkent province, Uzbekistan
}

\begin{abstract}
In recent years, the increase in grain yield under irrigated conditions has led to a decrease in technological quality of grain. The main reason for this is the lack of nitrogen during the grain formation in wheat on gray soils with low humus content. Under irrigated conditions, one of the most urgent tasks is to increase the grain yield of winter wheat and improve technological quality. According to the results of scientific research, today winter wheat absorbs $50-55 \%$ of nitrogen fertilizers, 20 $22 \%$ of phosphorus fertilizers and $55-60 \%$ of potassium fertilizers. Some of the nitrogen fertilizers not assimilated by the plant are released into the air in the ammonia state, while some are washed into the groundwater in the nitrite and nitrate state. This situation has a negative impact on the environment. This condition is prevented when the leaf orchids are fed, as well as the rate of absorption of phosphorus by the plant increases sharply.
\end{abstract}

\section{Introduction}

Full satisfaction of the population's demand for grain and grain products is one of the most urgent tasks in today's era of gradual transition to a market economy and the formation of new forms of ownership $[1,2]$.

According to the FAO, over the past 18 years, world grain production has reached 1.16 billion tons and increased by 2.3 billion tons. The most common cereal crop is wheat, which is grown on 227 million hectares in 120 countries. However, the world wheat yield is not high (27.1 quintal (q)/ha), which is not enough to meet the grain needs of the population. According to international organizations, the demand for wheat in the world is growing by $1.6-1.8 \%$ per year $[3,4]$.

Special programs have been developed to provide the population of the country with domestically grown grain, as a result of which the yield of winter wheat has increased 2.53.0 times [5]. That is, the yield increased from $14 \mathrm{q} / \mathrm{ha}$ to $57 \mathrm{q} / \mathrm{ha}$. The increase in grain yield was achieved mainly due to the use of advanced technologies in grain growing, planting high-yielding intensive varieties. Today, the yield of winter wheat on irrigated lands is $55-60 \mathrm{q} / \mathrm{ha}[6]$.

* Corresponding author: b.a.azizov@,yandex.ru 
During the years of independence, the country's grain yield has risen from 98th to 12th place. Today, the grain yield in Uzbekistan is higher than in European countries such as Italy, Spain, Portugal, Poland, and Sweden [7-9].

However, this productivity does not fully meet the growing demand of the population for grain products. Also, under irrigated conditions, the increase in winter wheat grain yield leads to a decrease in grain quality. Due to this, increasing grain yield and improving quality is one of the most urgent tasks [10].

Experiments by Sidorov have shown that the need for iron in plants can be fully met only by feeding through the leaves [11]. The importance and properties of leaf fertilization have been studied in the scientific works of Avdonin, Lebedev, Remeslo and other scientists [1-5, 11]. Professor Avdonin considers it expedient to use carbamide, one of the nitrogen fertilizers for plant fertilization from leaves [12]. Because, the amide nitrogen in the carbamide does not damage the leaves of the plant. According to Lebedev, plants best absorb iron and a number of trace elements through the leaves. Also, when fed through the leaves outside the root, the rate of assimilation of some later soluble mineral nutrients by the plant increases significantly [13].

Professor Rubin [7] studied the importance of extracurricular fertilization in plant growth and acceleration of important physiological processes in plants. According to Academician Remeslo [14], extra-root feeding of the plant at a very early stage, in the weeding phase, can lead to negative consequences, which can lead to damage to young seedlings and plant leaves. According to Professor Atabaeva and Azizov [15], leaf feeding of winter wheat should be considered as a supplementary feeding that provides the plant with nutrients during the growing season.

The importance of mineral fertilization and leaf fertilization in foreign countries has also been studied in the scientific works of several scientists [16-20].

From the above data, it can be seen that research on root feeding in cereals has been conducted mainly in Russia, Ukraine and a number of European countries. There is not enough scientific research in this area in our country [7-10]. Therefore, in our experiments, we studied the effect of leaf feeding on the yield and quality of winter wheat.

Therefore, the aim of the experiment is to determine the optimal concentration of carbamide suspension solution according to the developmental phases of the plant in the extra-root feeding of winter wheat under the conditions of typical irrigated gray soils. The study on the effect of non-root fertilization on the growth, development, grain yield and quality of winter wheat is also considered in this paper.

\section{Materials and methods}

The experiments are based on the methodology of Dospekhov [1-3]. All options were studied in four repetitions. The total area of each option is $100 \mathrm{~m}^{2}$, of which the calculated area is $50 \mathrm{~m}^{2}$.

The amount of humus in the soil was determined by the method of Tyurin, the total amount of nitrogen and phosphorus in the soil and vegetation was determined by the method of Keldal, Ginsburg, Sheglova, and Vilfius [6-9].

The amount of nitrate in the soil is determined by the Granval-Lyaju method, the amount of mobile phosphorus by the BI Machigin method, the amount of potassium by the fiery colorimeter method [6-9].

Agrophysical properties of soil are determined by the methods of Pavlov, Savinov, and Rizhov. The total leaf cover of winter wheat was determined by the method of Nichiparovich, biological productivity Shatilov and Kayumov, the amount of protein in the grain was determined by the Keldal method, the amount of gluten was determined by the washing method [7-11]. 
In the experiment, solutions of $5 \%, 10 \%, 15 \%$ of carbamide and $2.5 \%$ of phosphorus and potassium were fed in suspension through the extra-root leaves during three different stages of development of winter wheat: germination, grain-bearing, and blooming phases (Fig. 1).

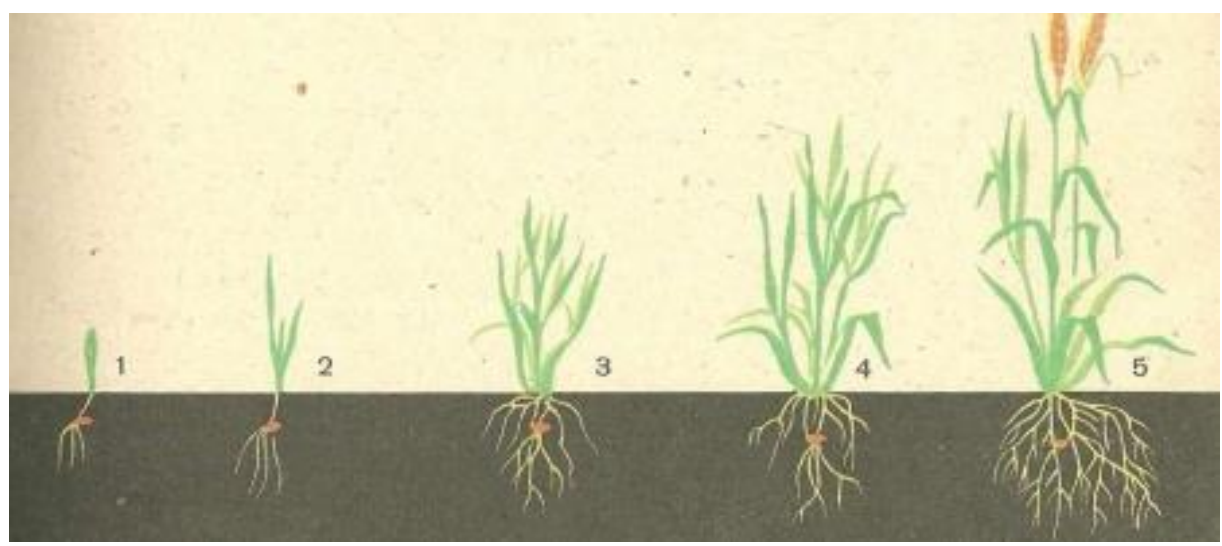

Fig. 1. Concentrated solution of suspension application during the growth period: 1 . Suspension $(0 \%)$; 2. Germination (5\%); 3. Emergence (7\%); 4. Grain-bearing (10\%); 5. Blooming (15\%).

The experiments were performed on 10 variants and four returns. All options and returns were placed in one tier.

\section{Results and discussion}

Leaf feeding is especially important in cereals, especially in the cultivation of winter wheat, especially in irrigated conditions; the application of this method in the nitrogen feeding of winter wheat ensures high efficiency.

Nitrogen requirements of winter wheat are high throughout the growing season. In a wheat plant, $75-80 \%$ of nitrogen accumulates in the leaves and stems of the plant until the sprouting phase. It is from this accumulated nitrogen that the bulk of the protein in the grain is formed. When the yield is high (65-70 $\mathrm{q} / \mathrm{ha})$, the amount of nitrogen accumulated in the leaves and stems of the plant does not ensure a sufficient amount of protein in the grain. Nitrogen deficiency is especially observed in winter wheat during the formation of yield elements, in the sprouting, flowering and milk ripening phases of development. However, there are a number of problems in feeding winter wheat at this stage.

According to the results of scientific research, today winter wheat absorbs $50-55 \%$ of nitrogen fertilizers, $20-22 \%$ of phosphorus fertilizers and $55-60 \%$ of potassium fertilizers. Some of the nitrogen fertilizers not assimilated by the plant are released into the air in the ammonia state, while some are washed into the groundwater in the nitrite and nitrate state. This situation has a negative impact on the environment.

This condition is prevented when the leaf orchids are fed, as well as the rate of absorption of phosphorus by the plant increases sharply. According to experimental results, about $95-98 \%$ of nitrogen and phosphorus fertilizers are absorbed by the plant when fed outside the root.

The grain yield of agricultural crops, including winter wheat, depends primarily on the seedling thickness of the plant, the production of grasses in the field that can provide a sufficiently high grain yield. Due to this, determining the seedling thickness of the plant is one of the most important requirements in all scientific research in the field of botany. 
Optimal seedling thickness and feeding area ensure that all physiological processes are accelerated. The microclimate in each option is improved. However, little is known about the positive effects of extra-root feeding on plant seedling thickness and yield. Due to this, the scientific research carried out in this area is of great scientific and practical importance.

Seedling thickness of the plant depends primarily on the rate and duration of planting. However, obtaining a flat seedling and maintaining the grass also depends to some extent on mineral fertilization. In addition to the root, the method of feeding the plant from the leaves plays an important role in the production of a flat seedling. In addition to the root of winter wheat, when fed by leaves, the plant's immunity to sucking pests increases.

In the experiment, the seedling thickness of the plant was carried out three times during the season: in late autumn, early spring and during the ripening phase. Observations were made according to the methodology defined in the plants marked with a separate label in the calculated areas of each variant. The productive accumulation of the plant is carried out twice: at the end of the accumulation phase and at the beginning of the tube wrapping phase.

Calculations for determining the seedling thickness of winter wheat, the calculations are determined by counting in the calculated area of each variant, in the area of $1 \mathrm{~m}^{2}$. Data on the positive effect of off-root feeding on seedling thickness and yield accumulation of winter wheat in the experiment are presented in Table 1.

Table 1. Seedling thickness of winter wheat by development phases.

\begin{tabular}{|c|c|c|c|c|}
\hline \multirow{2}{*}{$\begin{array}{c}\text { Development } \\
\text { phases }\end{array}$} & Fertilization & \multicolumn{3}{|c|}{ Number of plants per 1 m² } \\
\cline { 2 - 5 } & In fall & In spring & $\begin{array}{c}\text { In the } \\
\text { maturation } \\
\text { phase }\end{array}$ \\
\hline \multirow{7}{*}{ Germination } & $\begin{array}{c}\text { N200,P140,K90 } \\
\text { (Standard - ST) }\end{array}$ & 374 & 360 & 310 \\
\cline { 2 - 5 } & $\begin{array}{c}\text { ST - 5\% suspension } \\
\text { solution of carbamide }\end{array}$ & 376 & 367 & 355 \\
\cline { 2 - 5 } & $\begin{array}{c}\text { ST - 10\% suspension } \\
\text { solution of carbamide }\end{array}$ & 377 & 368 & 356 \\
\cline { 2 - 5 } & $\begin{array}{c}\text { ST - 15\% suspension } \\
\text { solution of carbamide }\end{array}$ & 379 & 370 & 358 \\
\hline \multirow{7}{*}{ Grain-bearing } & $\begin{array}{c}\text { ST - 5\% suspension } \\
\text { solution of carbamide }\end{array}$ & 378 & 369 & 357 \\
\cline { 2 - 5 } & $\begin{array}{c}\text { ST - 10\% suspension } \\
\text { solution of carbamide }\end{array}$ & 379 & 370 & 358 \\
\cline { 2 - 5 } & $\begin{array}{c}\text { ST - 15\% suspension } \\
\text { solution of carbamide }\end{array}$ & 381 & 372 & 361 \\
\hline \multirow{3}{*}{ Blooming } & $\begin{array}{c}\text { ST - 5\% suspension } \\
\text { solution of carbamide }\end{array}$ & 375 & 367 & 356 \\
\cline { 2 - 5 } & $\begin{array}{c}\text { ST - 10\% suspension } \\
\text { solution of carbamide }\end{array}$ & 377 & 368 & 357 \\
\cline { 2 - 5 } & $\begin{array}{c}\text { ST - 15\% suspension } \\
\text { solution of carbamide }\end{array}$ & 379 & 370 & 361 \\
\hline
\end{tabular}

The results of the experiment showed that the number of plants per $1 \mathrm{~m}^{2}$ area depends mainly on the sowing rate and seed quality. No significant difference in seedling thickness was observed in the experiment. A slight advantage in seedling thickness was noted in the leaf-fed variants with a $15 \%$ suspension of winter wheat carbamide. In these variants, the number of plants per $1 \mathrm{~m}^{2}$ was 379-381, and the thickness of seedlings per 1 hectare was 3.79-3.81 million. 
The formation of a sufficiently general leaf cover on the plant is important in the formation of winter wheat grain yield and grain quality. Optimal growth and development of the plant, the formation of biological substances, productivity indicators depend primarily on the course of the process of photosynthesis, including the formation of an adequate leaf cover.

It is known that the plant forms a significant part of its crop, 90-95\%, all organic matter due to photosynthesis, only $5 \%$ of the mass falls on minerals. Hence, we need to ensure that the process of photosynthesis is optimal for high yields.

Only at the leaf cover of the plant are organic substances synthesized from inorganic substances during photosynthesis. Due to this, we need to form a sufficient number of leaf rows in the field to grow a high and quality grain crop. All physiological processes that take place in the plant: photosynthesis, transpiration, metabolism, aeration take place directly in the presence of leaves. The process of photosynthesis, the formation of organic mass depends on each plant and the overall leaf surface. The grain yield of all agricultural crops, including winter wheat, depends on the index of the leaves. The leaf index (Equation 1) is the ratio of the total leaf surface to the area per unit area. That is, the ratio of the total leaf area per hectare to the area per hectare.

Where, I - leaf index, L - total leaf cover, and S - surface area per hectare.

In order for photosynthesis to accelerate in the field, the leaf index should be between 34.The application of the leaf prediction method is of great importance in determining the optimal norms and terms in the extra-root feeding of plants. Leaf diagnostics, i.e. the method of prediction based on leaf color, is shown in Fig. 2.

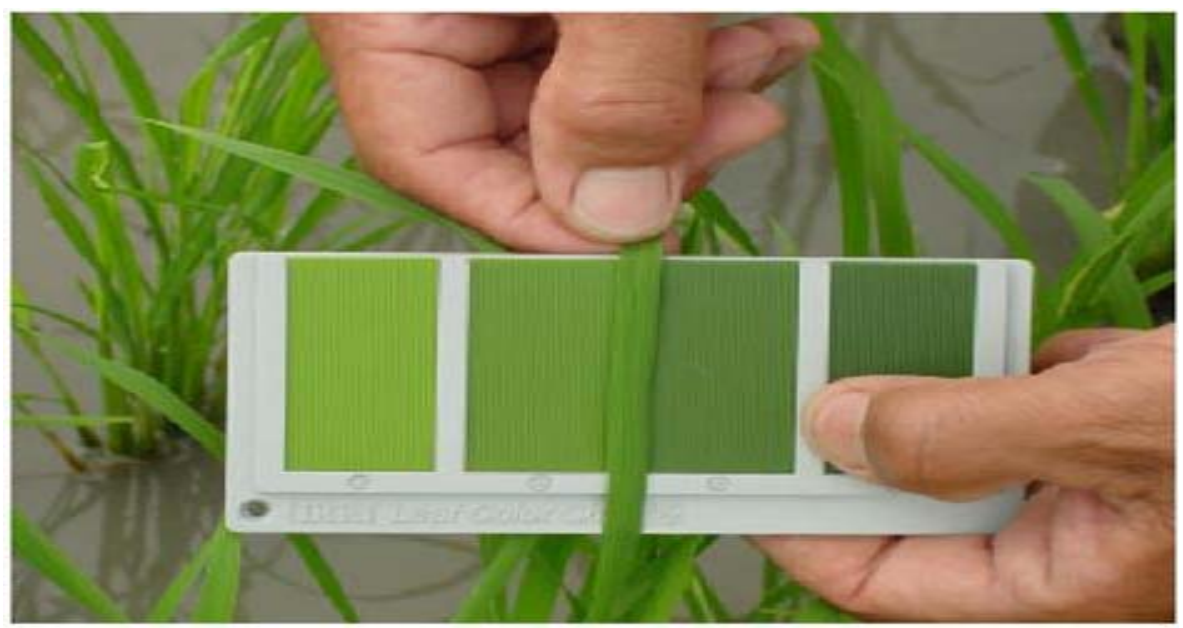

Fig. 2. Prediction of winter wheat in field conditions based on leaf color.

Data on the positive effect of the concentration of the suspension solution on the formation of the total leaf cover under non-root-fed conditions are given in Table 2.

Extra-root fertilization has a positive effect on the formation of the overall leaf surface in the plant. In the experimental control variant, the total leaf cover in the field was 35,800 $\mathrm{m}^{2} /$ ha, $41,200 \mathrm{~m}^{2} /$ ha under leaf feeding under a $5 \%$ suspension solution of carbamide in the tubing phase, and $43,600 \mathrm{~m}^{2} /$ ha under leaf feeding under a $10 \%$ suspension solution. When fed from the leaf with a $15 \%$ suspension solution, it was $45,300 \mathrm{~m}^{2} / \mathrm{ha}$. 
Table 2. Effect of extra-root feeding on the total leaf cover of winter wheat.

\begin{tabular}{|c|c|c|c|c|}
\hline \multirow{2}{*}{$\begin{array}{l}\text { Development } \\
\text { phases }\end{array}$} & \multirow{2}{*}{ Fertilization } & \multicolumn{3}{|c|}{ Leaf cover, ${ }^{\prime} 000 \mathrm{~m}^{2} / \mathrm{ha}$} \\
\hline & & Mar 1 & Apr 1 & May 1 \\
\hline - & $\begin{array}{l}\text { N200,P140,K90 } \\
(\text { Standard - ST) }\end{array}$ & 3.9 & 16.0 & 35.8 \\
\hline \multirow{3}{*}{ Germination } & $\begin{array}{l}\text { ST - 5\% suspension } \\
\text { solution of carbamide }\end{array}$ & 3.9 & 18.5 & 41.2 \\
\hline & $\begin{array}{l}\text { ST - } 10 \% \text { suspension } \\
\text { solution of carbamide }\end{array}$ & 4.0 & 19.7 & 43.6 \\
\hline & $\begin{array}{l}\text { ST - } 15 \% \text { suspension } \\
\text { solution of carbamide }\end{array}$ & 4.1 & 20.5 & 45.3 \\
\hline \multirow{3}{*}{ Grain-bearing } & $\begin{array}{c}\text { ST - 5\% suspension } \\
\text { solution of carbamide }\end{array}$ & 3.9 & 18.2 & 42.0 \\
\hline & $\begin{array}{l}\text { ST - } 10 \% \text { suspension } \\
\text { solution of carbamide }\end{array}$ & 4.0 & 20.0 & 44.2 \\
\hline & $\begin{array}{l}\text { ST - } 15 \% \text { suspension } \\
\text { solution of carbamide }\end{array}$ & 4.0 & 21.4 & 46.3 \\
\hline \multirow{3}{*}{ Blooming } & $\begin{array}{c}\text { ST - 5\% suspension } \\
\text { solution of carbamide }\end{array}$ & 3.9 & 18.5 & 42.2 \\
\hline & $\begin{array}{l}\text { ST - } 10 \% \text { suspension } \\
\text { solution of carbamide }\end{array}$ & 4.0 & 20.4 & 44.6 \\
\hline & $\begin{array}{l}\text { ST - } 15 \% \text { suspension } \\
\text { solution of carbamide }\end{array}$ & 4.1 & 21.7 & 47.1 \\
\hline
\end{tabular}

The total leaf area in the field was $42.0-46.300 \mathrm{~m}^{2} /$ ha, respectively, in the conditions when the winter wheat was fed outside the root in the developmental stage. A relatively high rate was observed in the extra-root-fed variant with a $15 \%$ suspension solution of carbamide at $46,300 \mathrm{~m}^{2} /$ ha.

Under non-root-fed conditions during the flowering phase, the total leaf cover in the field was $42.2,44.6$ and $47.300 \mathrm{~m}^{2} /$ ha, respectively. The highest rate was recorded at $47,300 \mathrm{~m}^{2} /$ ha under $15 \%$ suspension during the flowering phase.

Therefore, in order to increase the total leaf cover in the field under irrigated conditions, it is advisable to feed the winter wheat extra-root with a $15 \%$ suspension solution of carbamide.

In the later stages of development, i.e. during the period of germination and flowering, an increase in the total leaf cover in the field was observed. This, in turn, provided an increase in the efficiency of leaf feeding. Improving the technological quality of grain in grain growing is one of the most pressing tasks because the quality of the product depends primarily on the quality of the grain. Technological quality indicators of grain include grain transparency, flour strength, grain protein and gluten content.

It is known that the increase in grain yield of winter wheat under irrigated conditions often leads to a decrease in the technological quality of grain. Because the content of humus in the gray soils of the republic is low, there is a shortage of nitrogen in the soil in conditions of increased productivity. That is, during this period in the gray soil there are less mobile nitrogen reserves in the nitrate state that the plant can assimilate, the plant's need for nitrogen increases during the grain formation period because the protein contains $16-17 \%$ nitrogen. Therefore, under irrigated conditions, nitrogen feeding is definitely advisable during the grain formation period. However, there are a number of problems with nitrogen fertilization in grain fields during this period.

One of the most effective methods of nitrogen feeding at these stages of development is the feeding of winter wheat outside the root, i.e. through the leaves. The positive effect of off-root feeding on the technological quality of grain is shown in Table 3. 
Table 3. Effect of off-root feeding on grain quality of winter wheat.

\begin{tabular}{|c|c|c|c|c|c|}
\hline \multirow{2}{*}{$\begin{array}{c}\text { Development } \\
\text { phases }\end{array}$} & \multirow[b]{2}{*}{ Fertilization } & \multirow{2}{*}{$\begin{array}{l}\text { Transpa } \\
\text { rency, } \%\end{array}$} & \multirow{2}{*}{$\begin{array}{c}\text { Flour } \\
\text { product } \\
\text { ivity } \\
\end{array}$} & \multicolumn{2}{|c|}{ Contents in a grain, $\%$} \\
\hline & & & & Protein & Gluten \\
\hline- & $\begin{array}{l}\text { N200,P140,K90 } \\
\text { (Standard - ST) }\end{array}$ & 80 & 210 & 11.6 & 26.8 \\
\hline \multirow{3}{*}{ Germination } & $\begin{array}{c}\text { ST - 5\% suspension } \\
\text { solution of carbamide }\end{array}$ & 86 & 235 & 12.6 & 27.6 \\
\hline & $\begin{array}{l}\text { ST - } 10 \% \text { suspension } \\
\text { solution of carbamide }\end{array}$ & 87 & 250 & 12.9 & 28.2 \\
\hline & $\begin{array}{l}\text { ST - } 15 \% \text { suspension } \\
\text { solution of carbamide }\end{array}$ & 89 & 253 & 13.1 & 29.5 \\
\hline \multirow{3}{*}{ Grain-bearing } & $\begin{array}{c}\text { ST - 5\% suspension } \\
\text { solution of carbamide }\end{array}$ & 87 & 257 & 12.7 & 28.0 \\
\hline & $\begin{array}{l}\text { ST - } 10 \% \text { suspension } \\
\text { solution of carbamide }\end{array}$ & 90 & 288 & 13.0 & 29.1 \\
\hline & $\begin{array}{l}\text { ST - } 15 \% \text { suspension } \\
\text { solution of carbamide }\end{array}$ & 91 & 292 & 13.3 & 31.4 \\
\hline \multirow{3}{*}{ Blooming } & $\begin{array}{l}\text { ST - 5\% suspension } \\
\text { solution of carbamide }\end{array}$ & 88 & 289 & 12.8 & 27.9 \\
\hline & $\begin{array}{l}\text { ST - } 10 \% \text { suspension } \\
\text { solution of carbamide }\end{array}$ & 90 & 305 & 13.2 & 29.9 \\
\hline & $\begin{array}{l}\text { ST - 15\% suspension } \\
\text { solution of carbamide }\end{array}$ & 92 & 309 & 13.6 & 31.7 \\
\hline
\end{tabular}

In the control variant, the transparency of the grain was $80 \%$, the flour productivity was 210 , the protein content of the grain was $11.6 \%$, and the gluten content was $26.8 \%$.

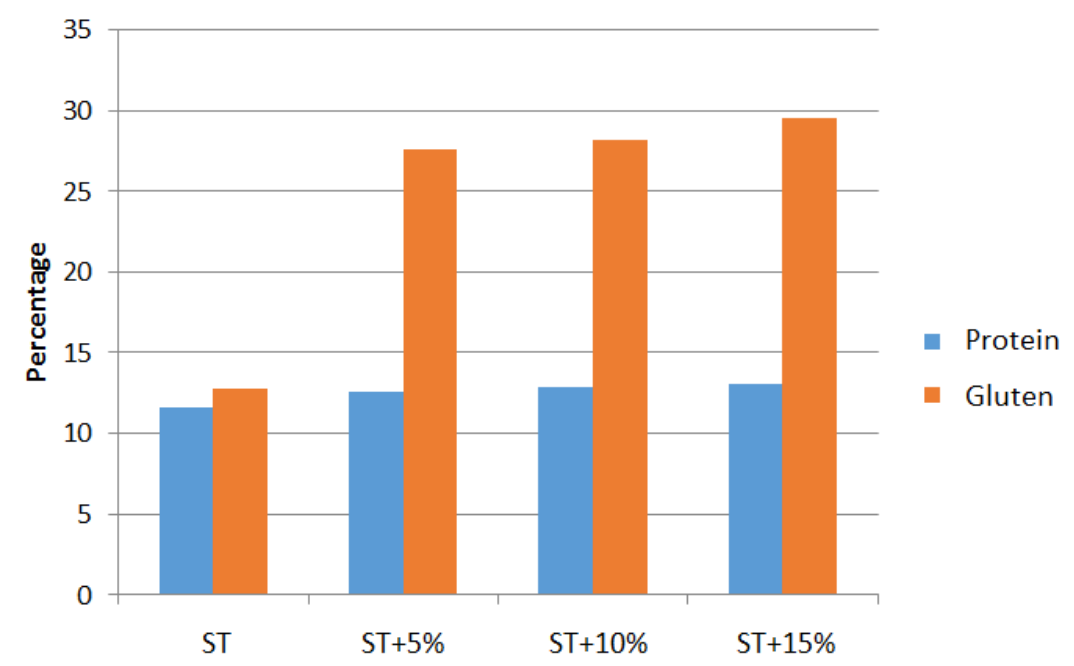

Fig. 3. Effect of leaf feeding on the quality of winter wheat grain (germination phase).

In the experiment, in all studied variants, the technological quality of grain was higher than in the control variant. In the non-root-fed variants, the transparency of the grain was $86-91 \%$, the protein content of the grain was $12.6-13.6 \%$, and the gluten content was 27.6$31.7 \%$. Relatively high grain quality was observed in the variant of root feeding with a $15 \%$ suspension solution of carbamide in the flowering phase of winter wheat. In this variant, the 
protein content of the grain was $13.6 \%$ and the gluten content was $31.7 \%$. The quality of the grain fully meets the requirements of a strong wheat standard (Fig. 3).

One of the most important indicators in grain growing is grain yield. Cereals are grown for planting, including winter wheat. Therefore, increasing grain yield is one of the most urgent tasks.

To increase grain yield, it is necessary to use new innovative technologies in grain growing. One such innovative technology is the feeding of winter wheat through the leaf outside the root.

Data on the positive effect of off-root feeding on winter wheat grain yield in the experiment are presented in Table 4.

Table 4. Effect of off-root feeding on winter wheat grain yield, $\mathrm{q} / \mathrm{ha}$.

\begin{tabular}{|c|c|c|c|}
\hline $\begin{array}{l}\text { Development } \\
\text { phases }\end{array}$ & Fertilization & $\begin{array}{l}\text { Average grain } \\
\text { yield, } \mathbf{q} / \mathbf{h a}\end{array}$ & $\begin{array}{l}\text { Additional grain } \\
\text { yield, } \mathbf{q} / \mathbf{h a}\end{array}$ \\
\hline- & $\begin{array}{l}\text { N200,P140,K90 } \\
\text { (Standard - ST) }\end{array}$ & 54 & - \\
\hline \multirow{3}{*}{ Germination } & $\begin{array}{c}\text { ST - 5\% suspension solution } \\
\text { of carbamide }\end{array}$ & 66 & 12 \\
\hline & $\begin{array}{c}\text { ST - 10\% suspension solution } \\
\text { of carbamide }\end{array}$ & 67 & 13 \\
\hline & $\begin{array}{c}\text { ST - 15\% suspension solution } \\
\text { of carbamide }\end{array}$ & 69 & 15 \\
\hline \multirow{3}{*}{ Grain-bearing } & $\begin{array}{c}\text { ST - 5\% suspension solution } \\
\text { of carbamide }\end{array}$ & 68 & 14 \\
\hline & $\begin{array}{l}\text { ST - 10\% suspension solution } \\
\text { of carbamide }\end{array}$ & 69 & 15 \\
\hline & $\begin{array}{l}\text { ST - 15\% suspension solution } \\
\text { of carbamide }\end{array}$ & 71 & 17 \\
\hline \multirow{3}{*}{ Blooming } & $\begin{array}{c}\text { ST - 5\% suspension solution } \\
\text { of carbamide }\end{array}$ & 65 & 11 \\
\hline & $\begin{array}{c}\text { ST - 10\% suspension solution } \\
\text { of carbamide }\end{array}$ & 67 & 13 \\
\hline & $\begin{array}{l}\text { ST - } 15 \% \text { suspension solution } \\
\text { of carbamide }\end{array}$ & 69 & 15 \\
\hline
\end{tabular}

The results of the experiments showed that extra-root feeding has a positive effect on the growth and grain yield of winter wheat. In all the variants studied in the experiment, it was observed that the grain yield was higher than the control variant.

In the experiment, the grain yield was $54 \mathrm{q} /$ ha under mineral ST, under root feeding, while the grain yield was 65-71 q/ha in the variants using extra-root feeding. An increase in grain yields by 11-17 q/ha was observed due to non-root feeding. The highest grain yield was observed at $71 \mathrm{q} / \mathrm{ha}$ in the winter wheat sprouting phase under conditions of extra-root feeding with a $15 \%$ suspension solution of carbamide.

\section{Conclusions and recommendations}

1. A slight advantage in seedling thickness was noted in the leaf-fed variants with a $15 \%$ suspension of winter wheat carbamide. In these variants, the number of plants per $1 \mathrm{~m}^{2}$ was 379-381, and the thickness of seedlings per 1 hectare was 3.79-3.81 million.

2. According to the results of experiments, about $95-98 \%$ of nitrogen and phosphorus fertilizers are absorbed by plants when fed outside the roots. 
3. In the flowering phase, under conditions of extra-root feeding, the total leaf cover in the field was 42,2, 44,6 and 47,300 $\mathrm{m}^{2} /$ ha, respectively. The highest rate was recorded at $47,300 \mathrm{~m}^{2} /$ ha in the flowering phase under conditions of application of $15 \%$ suspension.

4. Relatively high indicators of grain quality were observed in the variant of root-feeding with a $15 \%$ suspension solution of carbamide in the flowering phase of winter wheat. In this variant, the protein content of the grain was $13.6 \%$ and the gluten content was $31.7 \%$. The quality of the grain fully meets the requirements of a strong wheat standard.

5. In the mineral background, under the conditions of root feeding, the grain yield was 54 $\mathrm{q} / \mathrm{ha}$, while in the case of extra-root feeding, the grain yield was $65-71 \mathrm{q} / \mathrm{ha}$. An increase in grain yields by 11-17 q/ha was observed due to non-root feeding.

In order to increase the grain yield of winter wheat and improve the technological quality of grain under irrigated conditions, it is recommended to feed the roots with a solution of $7-10 \%$ of carbamide in the initial accumulation, germination and germination phases of development and 15\% suspension solution in the flowering-wax ripening phase.

Extra root feeding of bacterial preparations such as Baikal, Zamin-M, Fostim and micro-fertilizers such as calcium $(\mathrm{Ca})$, iron $(\mathrm{Fe})$, magnesium $(\mathrm{Mg})$, and barium $(\mathrm{B})$ with a $10-15 \%$ suspension solution of carmomite further enhances the effectiveness of mineral fertilizers is recommended for increased yield production.

To further improve the quality of off-root fertilization, it is recommended to develop complex fertilizers enriched with bacterial nutrients and micronutrients along with macro fertilizers.

\section{References}

1. N.Ch. Namozov, D.A. Kodirova, M.I. Usmonova, International journal of scientific \& technology research, 9(03), 5491-5493 (2020)

2. M. Urmanova, A. Kuziev, D. Burkhanova, D. Kadirova, N. Namozov, N. Shadieva, E3S Web of Conferences, 244, 02036 (2021)

3. S. Islamov, N. Namozov, M. Saidova, D. Kodirova, E3S Web of Conferences, 244, 03028 (2021)

4. B. Azizov, I.A. Israilov, B.Y. Nurkulov, Effect of foliar nutrition on the formation of productive organs of winter wheat, 1, 12-15 (2013)

5. N. Namozov, M. Tursinbaev, I. Yuldoshev, S. Yuldasheva, E3S Web of Conferences, 244, 02007 (2021)

6. M. Karimov, N. Namozov, B. Teshaboev, E3S Web of Conferences, 244, 02025 (2021)

7. B.A. Rubin, Plant Physiology Course, 326-358 (1963)

8. B. Azizov, F. Muhtarov, B. Isroilov, Influence of fertilizers on sowing quality of winter wheat seed of Uzbekistan, 159-163 (2017)

9. B. Azizov, B. Israilov, A. Kurbonov, E. Khujamiayrov, The Way of Science, 8(42), 9 (2017)

10. I. Israilov, B.M. Azizov, Influence of spray fertilization on grain technological quality, 12-17 (2015)

11. R.A. Kulmatov, A.A. Kist, IND. LAB, 44(12), 1689-1692 (1978)

12. V.M. Emets, R.A. Kulmatov, Doklady Biological Sciences, 271(1-6), 370-372 (1983)

13. B. Abdullaev, R.A. Kulmatov, A.A. Kist, Industrial Laboratory (USSR) (English translation of Zavodskaya Laboratoriya), 54(7), 710-713 (1989) 
14. R.A. Kulmatov, V.S. Savenko, N. Dalonov, Geochemistry International, 29(5), 140148 (1992)

15. V.S. Savenko, R.A. Kulmatov, Geochemistry International, 35(11), 1028-1030 (1997)

16. S.K. Isaev, R.U. Rakhmonov, S.S. Tadjiev, G.I. Goziev, S.Z. Khasanov, IOP Conference Series: Earth and Environmental Science, 614(1), 012147 (2020)

17. S. Isaev, I. Begmatov, G. Goziev, S. Khasanov, IOP Conference Series: Materials Science and Engineering, 883(1), 012080 (2020)

18. S. Isaev, S. Khasanov, Y. Ashirov, T. Karabaeva, A. Gofirov, E3S Web of Conferences, 244, 02012 (2021)

19. S. Isaev, S. Khasanov, Y. Ashirov, A. Gofirov, T. Karabaeva, In E3S Web of Conferences, 244, 02047 (2021)

20. D. Quist, L. Chapela, Nature (London), 414, 541-543 (2001) 